\title{
Reflection of Ex -Tea Tribe Community of Assam and its Marginalization: A Socio-Cultural Transformation: Case Study of Biswanath Chariali District of Assam
}

\author{
Dr. Banasmita Nath \\ Ex-Research Scholar, Ranchi University
}

\begin{abstract}
This study investigate the influence of resilience and self-esteem among undergraduate college students (N=110) in Chennai district, Tamil Nadu. An exploratory design is used among undergraduate students using purposive random sampling technique. In this case, two questionnaires are administered, Self-esteem is assessed by using the Rosenberg selfesteem scale (1965) and English version of Resilience Scale - RS-14 is also used in this study (Wagnild, 2010). Correlational and regression analysis shows statistically significant relationships between resilience and self-esteem $(\mathrm{r}=0.24 * *, \mathrm{P}<0.01)$. Self-esteem can be considered a predictor of resilience, which suggests resilience based intervention, should be provided for the students to improve their self-esteem.
\end{abstract}

Keywords - Self-esteem; Resilience; College Students

\section{Introduction}

Ex-Tea Garden Labour was used by Royal Commission on Labour(1931). They are also termed as Extea tribes and Ex-tea labour. In Assamese language they are called Practon Chah Bonua or Practon Chah Majdoor. In fact many of them are no longer labourers. The word 'labour' or 'labourers' is used to qualify this section irrespective of their present occupations. The ex-tea garden labour community has a particular historical background and their emergence was due to recruitment of labour from outside the state province in 1860 to work in the tea garden. As the local people denied to work as the labour in their own land so in order to meet the needs of surplus labour for expanding tea garden plantation large number of people were brought from outside the state. The settlement pattern of the ex-tea garden community continued till after the abolition of indenture system in 1925 .

\subsection{Objectives of the Study}

- To explore the present socio-economic, cultural and political life of migrated tea tribes in Assam.

- To understand the extent of socio economic change of tea tribes

\subsection{Significance of Study}

The socio-economic status of Ex-Tea Tribess community manifests their plight which has been continuously ignored for generation. There is an age old demand for recognition as scheduled tribe so that they can also enjoy the constitutional rights under the policy of reservation. It is pertinent here to mention that the tribal communities post their migration to Assam tea garden are not scheduled under scheduled tribe status. Ironically they are still under schedule tribe canopy back in their origin native state of Jharkhand. To augment the situation the apathy of main stream Assamese society towards the development of tea garden labourers inculcates the ethnic clashes.

\section{Literature Review}

A lot of work has been done on migration but same cannot be said about the migrants from Jharkhand to Assam tea garden. To the best of my knowledge there is lack of concrete and significant work on it. Some of the works on migration that I came across are as follows: one of the important studies endeavoured by Anup Karan independently was, 'Changing Patterns of Migration from Rural Bihar', (2003) in the book entitled: Migrant Labour and Human Rights in India", edited by G. Iyer. Karan writes about the changing pattern discussing the socio economic status, choice of destination etc.

Sanjoy Hazarika on the other hand in his book "Rites of Passage", talks about migrant and their socio cultural aspects. The aspects that might considered as characterizing of the "reception of migrant" or the response of receiving migrant. Nair (1983) studied the impact of gulf migration along with the causes of emigration and also examined the socio-economic changes and characteristic of migrants and utilization of foreign remittances. It reflect the pull and push factor forced the Keralites to migrate to Gulf region. Nair also observed that the higher socioeconomic status of the emigrants may create conflict between the rich one and the old rich. He points the negative and positive impact of emigration at the household level. 


\section{Theoretical Perspective}

A different approach emerged to interpret migration which has its intellectual roots in Marxist political economy and world system theory (Castles and Miller 2003) and the approach is known as Historical- structural theory. The theory postulates that economic and political power is unequally distributed among the developed and underdeveloped countries and people have unequal resources and capitalist expansion has the propensity to emphasize those inequalities. Instead of modernizing and gradually succeeding towards economic development underdeveloped countries are ensnared by their deprived position within the global geopolitical configuration.

There is another theory developed by geographer Mabogunje (1970). According to this theory migration alters the social, cultutal, economic and institutional conditions of both area during the whole process of migration.Most of the theories for the study of migration have been influenced from qualitative anthropology, sociology, human geography and cultural studies. Most of the approaches reflect the 'cultural turn' in social sciences for instance human geography research switch its paradigm from quantitative population geographer to qualitative cultural geographer (Blunt 2007; King 2012). In recent times, transnational process has dominated the field of migration studies. The two studies for the transnational approach were "Towards a Transnational Perspective on Migration (Glick Schiller et al. 1992) and Nations Unbound (Basch et al. 1994). The transnational approach focuses on the migrant activities that take place on the recurrent basis across national borders and that require a regular and significant commitment of the time of participants and these activities are not limited to economic activities but includes political, cultural and religious activities.

\section{Research Methodology}

Methodology mainly focuses on theoretical discussion about the research work which reflects about the aim, objective and significance of research method. Research Methodology is itinerary of action implicated in the exploration of information and ideas and theoretical outlining of the study focused upon anthropological approaches and methods for primary data collection includes interview and participation observation and secondary data was collected from case studies, articles and archives. I conducted a pilot survey on December 2014 for twenty days in Biswanath Chariali and the pilot study helped me solve some problems. It facilitated me to disembark at a proper methodological approach for my study among Ex-Tea Tribesss.

\section{Society}

The population of Assam is composed of different ethnic group from different state. The demographic pattern of the state changed after first flow of migrants during 1860 and the migrants were the tea garden laborers. The process of emergence of ex-tea garden labor community began after the enactment of the Inland Emigration Act (Bengal Act III) in 1863 and there are various reasons that led to the emergence of the ex-tea garden community which constitute distinctive demographic group. Most of the village was established prior to 1930. The period of settlement on the ex-tea garden can be determined on the basis of birth place of the head of the family.

Table 1. Age group of respondent living in tea garden and adjacent village

\begin{tabular}{|l|l|l|}
\hline Age & In Tea Garden & In Village \\
\hline $30-40$ & - & $4(3.25)$ \\
\hline $40-50$ & $9(7.31)$ & $7(5.69)$ \\
\hline $50-60$ & $21(17.07)$ & $42(34.14)$ \\
\hline 60 and above & $30(24.39)$ & $10(8.13)$ \\
\hline Total & $\mathbf{6 0}$ & $\mathbf{6 3}$ \\
\hline
\end{tabular}

There is a complex process of social interaction among the different group who migrated to tea garden. As they settled in the state they try to accumulate the culture of the local population and modified their own culture and customs and respect each other culture and the traditions. The adjustment in tradition was also observed in ex-tea garden community and no difference was observed on the basis of caste or tribe in the ex-tea garden labour community. The presence of diverse group present in the ex-tea garden labour community has deprived them for a cohesive social authority. Each of the group has their own group consciousness on the basis of caste or tribal identity and such group was not represented by a person. There is greater empathy among the members of same tea garden who settled in the village. The ex-tea garden labour lives in isolation from the Assamese society and they live in marginalized area where the social and economic interaction between them is not possible. In course of time they have developed a common dialect to communicate with mixed of some Assamese language known as 'Sadri' dialect or 'baganiya baat', though they practice their own ritual and culture but is has been observed that they have followed the Hindu tradition. Their settlement is known as bongali gaon (bongali village) such name appear in the official name of the village and even Census of India and another word which is commonly used for the tea garden labour and the ex-tea garden labour is coolie which meant for them and that carries a dishonor of inferiority and in Hindi the word mazdoor have been used and such word is 
still used by the educated Assamese society. It has been observed that the member of higher caste Assamese society regard the ex-tea garden labour community as inferior. The change in the pattern of language is due to modernization, urbanization, education and desire for better socioeconomic condition have contributed to change in their mother tongue. The Kurukh language have showed partial shift to majority language used by different groups in tea garden community. Ex-Tea Tribess community have shifted their mother tongue by adapting Bagania or Sadri dialect to delineate them and the young people expressed their adherence to the dominant language. In spite of advent of urbanization, industrialization the people still consider language, religion, and customs as cultural identity and consider that adoption of dominant cultural values is not a threat to their identity. When people come in contact with each of different linguistic group they tried to speak the common language to communicate with other people. In order to overcome the communicative barricade people seek to conciliate their own speech and result in wide variety of linguistic significance. It result in borrowing of lexis and in some other cases it may result in creation of new language which involves influence one language on the other.

The social relation among the tea garden workers and the neighbouring community can be made on the basis of certain conjecture. The social composition of the population around the tea garden varies from zone to zone. In Bishwanath Chariali caste like Ahoms, Moran constitutes the Assamese population. Similarly, Nepalis and Bengali also constitute the major part of the population. Ex-Tea Tribesss is understood in local idiom as reference to the tea garden worker. The ex-tea garden community are mostly agriculturist and their interaction with the local people has developed gradually. The ex-tea garden workers are in the lower stratum in the social hierarchy of the local people. The isolation of the group which was first initiated by the British and then subsequently continued by the local people led to the minimum cultural borrowing by the tea labour. The social relationship among tea garden workers and ex-tea garden workers are based mainly on kinship and marital ties. The ex-tea garden workers also have social relation with other tea estate on the basis of caste and tribal affinities. There are only few secondary social institutions between two groups other than school and colleges where only few of them get the opportunity to enter. The indigenous population considers the tea garden population as a separate group often referred as 'bagani' or 'coolie' of the lowest order of social hierarchy. The economic and social backwardness have causes the segregation of the extea garden workers from the mainstream Assamese society. An effort has been made by various organizations to integrate the tea garden workers in the Assamese society. The organization Assam Sahitya Sabha has integrated the Adivasi language and culture in their forum. The process of transmission of Assamese cultural traits which is assimilated in the culture of Ex-Tea Tribess has been evident. The dominant section of Assamese society has lessened its differentiation attitude towards them and facilitates the cultural adjustment. Socio- cultural integration is slow because matrimonial ties between the indigenous society and that of the tea garden worker have been restricted and the reason behind this is the social status of the ex- tea tribes being part of the indigenous society of the state. Among Oraonsome, they have occupied a remarkable position in the political sphere.

Ex-Tea Tribesss comes under the category of Other Backward Classes (OBC). Though it has been observed that $\mathrm{OBC}$ community of Assamese society regard the member of ex- tea tribe community as low status group though they have been designated the same OBC status like them. The integration of various cultures in the tea garden community led to the development and growth of the composite culture within the tea garden community. The heterogeneous group of ex- tea tribe community have preserved their traditional cultural practices and values but due to accumulation with the other group they have fostered a process of borrowing cultural attributes and formed a common tea garden culture, in which element of their own culture are found, culture of Odiya, Bengali can be traced and elements of Assamese culture is also found in their culture. The ex -tea tribes have recognized some attributes of the original culture including the native tribal songs songs and dance and festival like karam and sarhul which is the symbol of their unity among the various group in the tea garden and the shared way of life. They consider the Assamese festival as their own festival as they also celebrate Magh Bihu and Rangali Bihu which is the social and cultural representation of Assamese society. The perception of identity of the tea garden worker as a social category is very strong in compare to those of neighbouring tea garden. There is strong social identification among the tea garden worker as the community in Assam. The people who have left the tea garden and settled in basti and worked as agriculturist and identify themselves as the extea garden workers and they still consider as the part of the tea garden community and the bequest of the contribution and association with the tea garden thus continues.

The symbols and taxonomy that signify the identity of the ex- tea tribes needs a recognition and dignity in the society at larger aspect. Now, the educated community did not approve the use of the term coolie though they are commonly referred as Chah Mazdoor (tea labour community). The derogatory term coolie refer as race or caste of people meant for menial work (Sushil Kumar, Chah Bagisar Asamiya Sampraday, in assamese, Jorhat, 1983) the term coolie is not meaningfully applicable to the ex tea garden workers who are no longer associated with the tea garden. The young generation of the tea garden 
community prefers to call them as the chah jana jati meaning tea tribes or seuj-samoraday means green community. The term chah janajati have is now generally accepted in representing the tea workers. Chah Mazdoor Yuba Santha and Chah Mazdoor Chatra Santha of Partapgarh tea estate (11-12 November 1981) had two day convention for using appropriate word to refer the tea garden worker.

\section{Conclusion}

However, in recent time though the scenario have changed to some extent. Integration between the tea garden workers and that of local people has developed due to the constant efforts of the enlightened individual of both the communities at local level. The educational facilities provided to the ea garden children have opened a scope to have a different world view within them and get the opportunity to interact with the children and they get to know about the different aspect of the society surrounding them. The trade union and the social organization are making effort to change the social and economic condition of the people. The social changes among the tea garden worker are occurring slowly. The social dignity and political consciousness among them will lead to the overall development of the Ex-Tea Tribess community.

\section{References}

[1] Bhattacharjee , T. (1994) "Land alienation among the tribes in north Cachar district of Assam," in Tribes of north-east India: Biological and cultural perspectives. Edited by S.Sengupta. New Delhi: Gyan Publishing House.

[2] Biswas, J., Coppard, D., Rafique, A., Rana, K. and Sengupta, A. (2001) Seasonal Migration, Social Change and Migrants Rights:Lessons from West Bengal. Economic and Political Weekly, 8 December,pp. 4547-4559.

[3] Blalock, Herbert. (1967) Towards Theory of Minority Group Relations, New York Willey

[4] Bogarhus, E.S. (1928) Immigration and Race Attitudes. Boston D.C. Heath

[5] Borrie, W.D.(1959) The Cultural Integration of Immigrants. Paris: UNESCO

[6] Bose, Ashish. (1973) Studies in India's Urbanization 1901-1971. Bombay Tata McGraw Hill

[7] Bose,N.K (1968). "Calcutta:1964, A Social Survey", Lalvani Publishing House, Bombay.

[8] Boserup, E. (1970) Women's Role in Economic Development, London: Allen and Unwin 